\title{
EDITORIAL STAFF
}

\author{
Editor in Chief \\ Henry R. Huttenbach \\ (The City College-CUNY)
}

East European Editor

Andrus Park

(Academy of Sciences) Estonia

Canadian Editor

Orest Subtelny

(York University)
West European Editor

Frank Golczewski

(Univerdsität der Bundeswehr)

Japan Editor

Fumio Uda

(Sophia University, Tokyo)

Associate Editors Alexander Motyl (Columbia University) Leonid Rudnytsky (Shevchenko Scientific Society) Edward Wynot (Florida State University)

Assistant Editor Dallas Arnold (The City College - CUNY)

Book Review Editor ....Reuel Hanks (Kennesaw State College)

Managing Editor

Cooridnator Special Issues

Russian Issue Editor . Andris Skreija (The University of Nebraska, Omaha) ..Gabriel Simoncini (The City College-CUNY) Emil Pain (Center for Ethnopolitical Studies, Moscow)

\section{EDITORIAL BOARD}

Edward Allworth, Columbia University • Audrey L. Altstadt, University of Massachussetts • Seymour Becker, Rutgers University $\bullet$ Yaroslav Bilinsky, University of Delaware $\bullet$ Yaroslaw Bilocerkowycz, University of Dayton • Thomas Bird, Queens College (CUNY) • Ian Bremmer, Stanford University • Hélène Carrère D'Encausse, Intstitut d'études politiques de Paris • David Crowe, Elon College - Andrew Ezergailis, Ithaca College • Tibor Frank, Eötvös Lóránd University, Budapest • John Georgeoff, Purdue University • Toussaint Hocevar, University of New Orleans • Taras Hunczak, Rutgers University • Anatoly Khazanov, Hebrew University • Edward Lazzerini, University of New Orleans • Allen Lynch, University of Virginia • Rado Lencek, Columbia University • Bogdan Mieczkowski, Ithaca College • Peter Potichnyj, McMaster University • John S. Reshetar, University of Washington • Michael Rywkin, City College-CUNY • Anita Shelton (Eastern Illinois University) • Roman Szporluk, Harvard University • Ronald Wixman, University of Oregon.

The editors accept no responsibility for the statements of fact or opinion made by the contributors.

Nationalities Papers is published semi-annually (Spring and Fall) by the Association for the Study of the Nationalities of the USSR and Eastern Europe (ASN) with the support of the Simon H. Rifkind Center for the Humanities of the Division of Humanities of The City College of New York, and a grant from the Shevchenko Scientific Society in America.

Copyright ${ }^{(C)} 1993$ by the Association for the Study of the Nationalities of the USSR and Eastern Europe, Inc.

Typesetting by $\Sigma$ KATOKEФA $\Lambda$ O $\Sigma$ Publishing, New York, New York, U.S.A.

Printed by Book Crafters, Inc., Chelsea, Michigan 48118, U.S.A. 
